\title{
Analysis of hospitalization expenses of 610 HIV/AIDS patients in Nantong, China
}

Xun Zhuang ${ }^{1 \dagger}$, Yujia Chen ${ }^{1,2 \dagger}$, Zunyou Wu ${ }^{3}$, Sarah Robbins Scott ${ }^{3}$, Renfei $\mathrm{Lu}^{4}$, Zhengcheng Xu', Yuhui Yu', Wei Wang ${ }^{1}$, Luyao Cao', Yuanyuan Liang ${ }^{1}$, Gang Qin ${ }^{4^{*}}$ (1) and Meiyin Zou ${ }^{4^{*}}$

\begin{abstract}
Background: The goal of this study was to describe the expenses related to human immunodeficiency virus (HIV) and acquired immune deficiency syndrome (AIDS) management and care in Nantong Infectious Disease Hospital from October 2013 through June 2017.

Methods: The information of 610 HIV/AIDS inpatients were collected from the Electronic Medical Record System of the hospital. Univariate and path analysis were employed to evaluate the association between hospitalization expense and its related factors.

Results: The average hospitalization expenses per person was 5454 RMB (Renminbi, the currency of China, about $\$ 808$ USD) and 23,555 RMB (about \$3489 USD), respectively for HIV/AIDS patients. The average length of hospital stay was $10.0 \pm 5.5$ days for HIV patients and $21.7 \pm 12.4$ days for AIDS patients. For HIV patients, laboratory test fees constituted $37.46 \%$ of total expenses; while drug fees accounted for the largest proportion for AIDS patients. Path analysis indicated that the length of hospital stay was the most important factor affecting total expenses (total path coefficient $=0.563$ for HIV patients and 0.649 for AIDS patients). Total expenses for HIV-infected females was higher than that of males (total path coefficient $=0.217$ ), and the more complications led to higher expenses for AIDS patients.

Conclusions: Though antiretroviral therapy (ART) is provided for free in China, associated medical care, particularly hospitalizations and fees, continue to drive up the medical costs of patients living with HIV and AIDS. Understanding the factors influencing these costs are crucial for determining policies and strategies that can reduce the economic burden of HIV/AIDS patients in China.
\end{abstract}

Keywords: AIDS, HIV, Hospitalization expense, Path analysis

\section{Background}

Human immunodeficiency virus (HIV) and associated acquired immunodeficiency syndrome (AIDS) are global public health threats, due to their impact on the health and economic well-being of countries. Globally, more than 36 million people were living with HIV in 2017 and 1.8 million became newly infected with the disease in the same year [1]. In China, which is home to more than 1

\footnotetext{
* Correspondence: ntqingang@163.com; zoumeiyin@126.com

${ }^{+}$Xun Zhuang and Yujia Chen contributed equally to this work.

${ }^{4}$ Affiliated Infectious Disease Hospital of Nantong University, Nantong, Jiangsu 226000, People's Republic of China

Full list of author information is available at the end of the article
}

billion people, the HIV epidemic continues to thrive. According to the National AIDS Epidemic Report of China, there were 758,610 HIV-infected cases in 2017 [2], more than double the number of cases $(379,348)$ reported in 2010 [3]. More so, the disease was responsible for 26,787 deaths in the last year [2]. With the introduction of antiretroviral therapy (ART) however, treatment and management of HIV has drastically changed. In China, ART is provided for free to all diagnosed individuals, which can effectively inhibit virus replication and maintain a low level of viral load continuously, so as to prevent the spread of HIV and reduce the overall prevalence of HIV to less

(c) The Author(s). 2020 Open Access This article is licensed under a Creative Commons Attribution 4.0 International License, which permits use, sharing, adaptation, distribution and reproduction in any medium or format, as long as you give appropriate credit to the original author(s) and the source, provide a link to the Creative Commons licence, and indicate if changes were made. The images or other third party material in this article are included in the article's Creative Commons licence, unless indicated otherwise in a credit line to the material. If material is not included in the article's Creative Commons licence and your intended use is not permitted by statutory regulation or exceeds the permitted use, you will need to obtain permission directly from the copyright holder. To view a copy of this licence, visit http://creativecommons.org/licenses/by/4.0/ The Creative Commons Public Domain Dedication waiver (http://creativecommons.org/publicdomain/zero/1.0/) applies to the data made available in this article, unless otherwise stated in a credit line to the data. 
than $1 \%[3,4]$. The burden of disease however, or the death and loss of health due to HIV/AIDS or associated risk factors [5], continues to threaten the growth of China's health and economic sectors. As patients live longer, the potential for other complications and risk factors arise, leading to costly medical care.

Financial access is a limiting factor for many people throughout China, especially for those living with a chronic illness such as HIV. Numerous studies have aimed to estimate the associated management costs for HIV-positive patients. In particular, studies have shown that complications of the disease can lead to impaired immune function, which in turn can increase hospitalization rates, hospital expenses, and patients' financial burden [6, 7]. A recent report amongst HIVpositive patients in France published in 2018, showed that most patients presenting to the hospital with an opportunistic infection or at least one comorbidity had increased hospitalization costs [6]. Another study from South Africa showed that the average cost per HIV+ admission was \$1783 United States Dollars (USD), with patients hospitalized, on average, for 9.3 days [7]. In China, the government implemented policies aimed at reducing the economic strain placed upon HIV-positive patients to manage their disease. The government implemented the 'free antiretroviral treatment' policy and the 'appropriate reduction on expenditure of opportunistic infection treatment' in 2004 [8], which reduced associated expenses for HIV/AIDS patients. Though the government provides free testing and ART to patients, the costs of other necessary procedures, such as diagnostic and laboratory tests and drugs for opportunistic infections, are not covered; thus the amount actually paid by the patient can still be quite high $[9,10]$.

Multiple studies in China have aimed to assess the associated medical costs of people living with HIV in high prevalence areas. One study amongst female AIDS patients estimated that associated hospitalization expenses reached 3419 RMB (Renminbi, the national currency of China, or about \$515 USD), with drug costs to manage co-morbidities accounting for the largest proportion (48.54\%) of expenses [11]. Another study in Yunnan Province in southern China found that the average cost of hospitalization for people living with HIV/AIDS was 2822 RMB (about \$453 USD), of which the anti-toxicity reaction of highly active antiretroviral therapy (HAART) and anti-opportunistic infections were 882 RMB (about \$141.6 USD) and 885 RMB (about \$142.1 USD), respectively [10]. These studies however, have not accounted for the different costs of HIV-related care in high prevalence versus low prevalence areas. With limited budget to meet HIV service needs, questions around where best to allocate resources arise. Thus, as these previous studies assessed related cost of care in high prevalence areas, and the change of direct economic burden for AIDS was associated with the epidemic situation in the region [12], so we aimed to describe the costs of medical care and utilization of health services of HIV/AIDS patients residing in Nantong city in eastern China, a low-prevalence $(0.42 \%)$ area with over $90 \%$ viral suppression. The results of this study can inform potential future financial planning of HIV/AIDS related policy in China.

\section{Methods}

\section{Data collection}

This was a retrospective analysis conducted in Nantong City from October 2013 to June 2017. All the laboratory-confirmed HIV or AIDS patients, meeting the definitive criteria for HIV/AIDS in accordance with the Diagnosis for HIV/AIDS of National Health Commission of the People's Republic of China (2019) [13], who had been hospitalized at the Nantong Infectious Disease Hospital during the study period, were included. The Nantong Infectious Disease Hospital is the only hospital that treats HIV/AIDS patients in Nantong City. Medical records of the hospitalized patients were collected from the Electronic Medical Record System of the hospital. Members of the study team familiar with medical records and billing files used data collection forms to capture the following data: demographic characteristics, time of admission and discharge, disease diagnosis, hospitalization expenses, and clinical treatment records. Hospitalization expenses included the direct medical expenses of each patient, including costs of medication (medications for prevention and treatment of adverse events or opportunistic infections), laboratory tests, examinations, and medical service charges. Hospital expenditure data was collected from patient entry into the hospital until the end of their first hospital stay. For patients undergoing repeated hospitalizations, only data from their first admission was considered for this study. This study was approved by the Ethics Committee of Affiliated Infectious Disease Hospital of Nantong University. As this was a retrospective analysis of de-identified records data (i.e., no personally identifying information was collected), informed consent was not required.

\section{Calculation of expenses}

The hospitalization expenses were extracted directly from the electronic billing system of the hospital. The patients' hospital expenses during their first admission were divided into four categories: medications, laboratory tests, examinations, and medical service charges. Medications were those taken for the prevention and treatment of adverse events (ADEs) or opportunistic infections (OIs) only. We did not include the cost of antiretroviral therapy, as antiretroviral (ARV) drugs are provided for free in China. Laboratory tests were for 
diagnosing and monitoring patients' condition and ARVs efficacy, such as HIV viral load tests, CD4/CD8 cell counts, hematologic parameters, liver and kidney function tests, urinalysis, C-reactive protein (CRP) tests, Epstein-Barr virus (EBV), and cytomegalovirus (CMV) tests. Examinations included radiologic examinations, such as chest X-rays, computed tomography (CT), electrocardiogram (ECG), magnetic resonance imaging (MRI), and abdominal ultrasound. Lastly, medical service charges included the costs associated with counseling, infusions, bed use, and medical supplies. Due to the long time span of this study, in order to make the costs comparable, we used the 2017 consumer price index (CPI) published by the National Bureau of Statistics as a benchmark to discount the costs over the years.

\section{Statistical analysis}

Data were entered using Epi Data 3.1 and STATA version 14.0 software (STATA Corporation, College Station, Texas, USA) was used for all analyses. The $P$-value of less than 0.05 was considered as statistically significant. Patients were categorized into two groups: HIV patients (individuals who had not yet progressed to AIDS) and AIDS patients (patients who had progressed to AIDS) [13]. Standard descriptive statistics were used to describe the characteristics of HIV/AIDS patients. Normally distributed continuous data were expressed as means and standard deviations (SDs). The skewed hospitalization expenses data were expressed as median and interquartile range (IQR).

In uni-variate analysis, the factors influencing hospitalization expenses of HIV patients and AIDS patients were analyzed by Mann-Whitney $U$ test (for 2 subgroups) and Kruskal-Wallis test (for multiple subgroups). Path analysis was used to describe the direct and indirect effects between factors and hospitalization expenses. The direct, indirect, and total path coefficients indicate the direct effect of one variable on the dependent variable, the indirect effect on the dependent variable through other variables, and the comprehensive effect. In the path analysis, the term "effect" refers to the statistical effect, not the causal effect. A direct effect was the factor that had an immediate impact on the outcome (hospitalization expenses), while an indirect effect was considered as any factor working through one or more intermediate variables, which impacted hospitalization expenses. The path analysis model was gradually fitted through multiple linear regression analysis. All study variables with $P<0.2$ in the uni-variate analysis were included in the path analysis in order to investigate as many potential variables as possible. In our study, both the length of hospital stay and hospitalization expenses variables were highly skewed and regarded as endogenous variables, so they were converted into approximate normal distributions by natural logarithmic (ln) transformation (Table 1).

\section{Results \\ Demographic and clinical characteristics of 610 HIV/AIDS inpatients}

A total of 642 cases were reviewed, of which 32 cases were excluded for missing baseline $\mathrm{CD} 4+\mathrm{T}$ cell count data, leaving 610 cases included in the final analysis. Of the 610 patients, 142 were living with HIV and 468 had AIDS. Of those living with HIV, the male to female ratio was 2.9:1; the average age was $40.9 \pm 13.2$ years (range: $12-73$ years), the median $\mathrm{CD} 4+\mathrm{T}$ cell count at admission was 315.5 (IQR: 256.8-439.5) cells/ $\mu \mathrm{l}$; and the average length of hospital stay was $10.0 \pm 5.5$ days (range: 2 48 days) (Table 2).

Of the AIDS patients, the male to female ratio was 6.4: 1 , the average age was $46.1 \pm 13.0$ years (range: $11-76$ years), the median $\mathrm{CD} 4+\mathrm{T}$ cell count at admission was 63.5 (IQR: 18.0-165.0) cells/ $\mu$ l; and the average length of hospital stay was $21.7 \pm 12.4$ days (range: $1-75$ days) (Table 2). Generally, more AIDS patients were male, older, acquired their infection through heterosexual transmission, had longer hospital stays, and more complications than the enrolled HIV patients.

\section{Hospitalization expenses}

From October 2013 to June 2017, people living with HIV in Nantong City spent an average of 5454 RMB (about \$808 USD) for their related care, while AIDS patients had an average expense of 23,555 RMB (about $\$ 3489$ USD), as seen in Tables 3 and 4. For HIV patients, the cost of laboratory tests accounted for the largest proportion of care, with approximately $2043 \mathrm{RMB}$ (about \$303 USD) in associated fees. Examination and medication expenses (1602 RMB and 1590 RMB, \$237 USD and \$235 USD, respectively) were the second and third most costly portions of care, while medical service charges accounted 219 RMB (approximately \$32 USD) (Table 3).

The cost of medications was the largest cost associated with care for AIDS patients. AIDS patients spent, on average, 15,391 RMB ( $\$ 2280$ USD) for medication related fees. Medical service charges was responsible for the smallest proportion of AIDS patients' associated hospitalization costs, with approximately 963 RMB (\$143 USD) (Table 4).

\section{Uni-variate analysis of hospitalization expenses}

The uni-variate analysis showed that being a female and longer time spent in the hospital were factors related to higher hospitalization expenses $(P<0.05)$ among people living with HIV. For AIDS patients, the factors associated with higher hospitalization expenses were longer 
Table 1 Main factors and assignment table of hospitalization expenses

\begin{tabular}{lll}
\hline Variable code & Assignment & Value \\
\hline$Y_{2}, Y_{4}$ & In (Hospitalization expense) (HIV), & Hospitalization expense \\
$Y_{1}, Y_{3}$ & In (Hospitalization expense) (AIDS) & Length of hospital stay \\
$X_{1}$ & In (Length of hospital stay) (HIV), & \\
$X_{2-0}, X_{2-1}$ & In (Length of hospital stay) (AIDS) \\
$X_{3-0}, X_{3-1}, X_{3-2}$ & Actual age (years) & Age (years) \\
$X_{4-0}, X_{4-1}$ & $0:$ Male 1:Female & Gender \\
$X_{5-0}, X_{5-1}, X_{5-2}, X_{5-3}$ & $0: M S M 1:$ Heterosexual & Transmission route \\
\hline
\end{tabular}

HIV human immunodeficiency virus, AIDS acquired immune deficiency syndrome, MSM men who have sex with men

Table 2 The demographic and clinical characteristics of 610 HIV/AIDS inpatients

\begin{tabular}{|c|c|c|}
\hline Characteristics & $\operatorname{HIV}[\mathrm{n}(\%)](n=142)$ & $\operatorname{AIDS}[n(\%)](n=468)$ \\
\hline \multicolumn{3}{|l|}{ Gender } \\
\hline Male & $106(74.6)$ & $405(86.5)$ \\
\hline Female & $36(25.4)$ & $63(13.5)$ \\
\hline \multicolumn{3}{|l|}{ Age groups (years) } \\
\hline$<30$ & $38(26.8)$ & $70(15.0)$ \\
\hline $30-44$ & $44(31.0)$ & $120(25.6)$ \\
\hline $45-59$ & $49(34.5)$ & $205(43.8)$ \\
\hline $60-73$ & $11(7.7)$ & $73(15.6)$ \\
\hline \multicolumn{3}{|l|}{ Transmission route } \\
\hline MSM & $27(19.0)$ & $46(9.8)$ \\
\hline Heterosexual & $111(78.2)$ & $347(74.2)$ \\
\hline Other/unknown & $4(2.8)$ & $75(16.0)$ \\
\hline \multicolumn{3}{|c|}{ Length of hospital stay (days) } \\
\hline$<10$ & $89(62.7)$ & $89(19.0)$ \\
\hline $10-19$ & $48(33.8)$ & $130(27.8)$ \\
\hline $20+$ & $5(3.5)$ & $249(53.2)$ \\
\hline \multicolumn{3}{|c|}{ CD4 + T cell count at admission (cells $/ \mu l)$} \\
\hline$<200$ & $3(2.1)$ & $374(79.9)$ \\
\hline $200+$ & $139(97.9)$ & $94(20.1)$ \\
\hline \multicolumn{3}{|l|}{ Complications } \\
\hline 0 & $142(100.0)$ & $107(22.9)$ \\
\hline 1 & $0(0)$ & $117(25.0)$ \\
\hline 2 & $0(0)$ & 190 (40.6) \\
\hline $3+$ & $0(0)$ & $54(11.5)$ \\
\hline \multicolumn{3}{|l|}{ ART } \\
\hline Yes & $22(15.5)$ & 135 (28.8) \\
\hline No & $120(84.5)$ & $333(71.2)$ \\
\hline
\end{tabular}

HIV human immunodeficiency virus, AIDS acquired immune deficiency syndrome, MSM men who have sex with men, $A R T$ antiretroviral therapy hospital stay, CD4+ T cell count $<200$ cells $/ \mu$ l, and more complications $(P<0.05)$ (Table 5).

\section{Path analysis of hospitalization expenses}

For HIV patients, the path mathematical model showed that the length of hospital stay had the strongest, direct, positive association with hospitalization expenses (total path coefficient $=0.563$ ). Gender also had a direct, positive impact on hospitalization expense (total path coefficient $=0.217$ ). Females' hospitalization expenses was higher than that of males. However, there was no indirect effect on the hospitalization expenses (Table 6, Fig. 1). The coefficient of determination $\left(R^{2}\right)$ of the model was 0.569 .

For AIDS patients, The path mathematical also found that the length of hospital stay had the strongest, direct, positive association with hospitalization expenses with a path coefficient of 0.649 , while the number of complications had both direct and indirect impacts on hospitalization expenses (total path coefficient $=0.232$, 0.421 and 0.286 , respectively for the number of complication $=1,2$ and $\geq 3$ ) (Table 6, Fig. 2). The coefficient of determination $\left(R^{2}\right)$ of the model was 0.613 .

\section{Discussion}

In our study, we described the HIV/AIDS-associated expenses of 610 inpatients in Nantong City. Though free antiretroviral therapy for HIV/AIDS patients was implemented in China at the end of 2004 [8], patients still accrued associated care costs. The average expenses per HIV patient was 5454 RMB (about $\$ 808$ USD) for one hospital stay and 23,555 RMB (about \$3489 USD) per AIDS patient for one hospital stay. Though Nantong is considered an economically developed area, HIV/AIDS can lead to detrimental impacts on resources, particularly if a positive person is unable to work due to his or her illness. Further research to estimate these indirect costs, as well as to understand how patients and their 
Table 3 Hospitalization expenses for 142 HIV inpatients from 2013 to 2017

\begin{tabular}{|c|c|c|c|c|c|c|c|c|c|c|c|c|}
\hline \multirow{2}{*}{$\begin{array}{l}\text { Year } \\
\text { Hospitalization } \\
\text { expenses } \\
\end{array}$} & \multicolumn{2}{|l|}{2013} & \multicolumn{2}{|l|}{2014} & \multicolumn{2}{|l|}{2015} & \multicolumn{2}{|l|}{2016} & \multicolumn{2}{|l|}{2017} & \multicolumn{2}{|l|}{ Total } \\
\hline & $\begin{array}{l}\text { Median } \\
\text { (CNY) }\end{array}$ & $\begin{array}{l}\text { Mean } \\
\text { (CNY) }\end{array}$ & $\begin{array}{l}\text { Median } \\
\text { (CNY) }\end{array}$ & $\begin{array}{l}\text { Mean } \\
\text { (CNY) }\end{array}$ & $\begin{array}{l}\text { Median } \\
\text { (CNY) }\end{array}$ & $\begin{array}{l}\text { Mean } \\
(\mathrm{CNY})\end{array}$ & $\begin{array}{l}\text { Median } \\
\text { (CNY) }\end{array}$ & $\begin{array}{l}\text { Mean } \\
\text { (CNY) }\end{array}$ & $\begin{array}{l}\text { Median } \\
\text { (CNY) }\end{array}$ & $\begin{array}{l}\text { Mean } \\
\text { (CNY) }\end{array}$ & $\begin{array}{l}\text { Median } \\
\text { (CNY) }\end{array}$ & $\begin{array}{l}\text { Mean } \\
\text { (CNY) }\end{array}$ \\
\hline Medications & 26,103 & 26,103 & 2438 & 6066 & 2671 & 6653 & 15 & 820 & 158 & 1256 & 121 & 1590 \\
\hline Laboratory tests & 2834 & 2834 & 894 & 1546 & 1368 & 1799 & 2002 & 1980 & 2149 & 2196 & 2088 & 2043 \\
\hline Examinations & 3221 & 3221 & 3706 & 2885 & 3402 & 3396 & 1111 & 1362 & 1025 & 1607 & 1115 & 1602 \\
\hline $\begin{array}{l}\text { Medical service } \\
\text { charges }\end{array}$ & 804 & 804 & 260 & 654 & 535 & 476 & 46 & 147 & 46 & 232 & 46 & 219 \\
\hline Total & 32,962 & 32,962 & 7407 & 11,151 & 8086 & 12,324 & 3325 & 4309 & 3560 & 5291 & 3489 & 5454 \\
\hline
\end{tabular}

HIV human immunodeficiency virus, CNY Chinese Yuan

families are impacted by these healthcare costs, are needed.

A handful of factors were found to be associated with the increased hospitalizations costs amongst people living with HIV and AIDS in Nantong. For people living with HIV, gender directly affected hospitalization expenses. Females' hospitalization expenses was 761 RMB (about \$113 USD) more than that of males. The gender difference in hospitalization expenses may not be due to factors of gender itself, but perhaps to adherence to ART. Previous research has shown that females are more sensitive to symptoms, such as allergies or gastrointestinal reactions during ART, resulting in poorer adherence compared to males [14]. In turn, this can lead to more serious illness and higher hospitalization expenses for females. A follow-up assessment determining such factors associated with this higher cost could help inform gender-specific guidelines when assessing HIVbudgetary needs. This study also showed that for those living with HIV, the cost of laboratory tests accounted for the largest portion (37.46\%) of associated in-patient costs, as those living with HIV may require semi-regular biochemical tests in order to track their disease progression while infected. Additional changes to current insurance policies, which promote reimbursement for laboratory tests could help lower patients' financial burden and promote compliance [15].
In our study, the average hospitalization expenses of AIDS patients was 23,555 RMB (about \$3489 USD), which is higher than a study in a hospital in Lanzhou, China reported of 15,714 RMB (about \$2470 USD) [16]. The higher hospitalization expenses of AIDS in Nantong was related to the regional economic level and hospital grade [11, 12]. Nantong is located in an economically developed region in eastern China, which meant that local patients had greater health needs and stronger personal payment ability. Nantong Infectious Disease Hospital is a third-grade hospital, while the Infectious Hospital of Gansu Province, where the study in Lanzhou took place, is a second-grade hospital. Therefore, the higher grade the hospital, the larger expenditure patients will have to pay. Thus, not only should prevalence be considered when determining how best to allocate resources, but so should the economic viability of those infected. For AIDS patients, the cost of treatment for AIDS complications accrued a large economic burden [17], accounting for the largest portion of their expenses. This was consistent with other findings from Guangxi, China, which showed that the cost of medications constituted $65.33 \%$ of total expenses of AIDS infected patients [18]. Additionally, the number of complications not only directly affected hospitalization expenses, but also indirectly affected expenses through the length of hospital stay, indicating that the more complications or the more serious the condition an AIDS patient had, the

Table 4 Hospitalization expenses for 468 AIDS inpatients from 2013 to 2017

\begin{tabular}{|c|c|c|c|c|c|c|c|c|c|c|c|c|}
\hline \multirow{2}{*}{$\begin{array}{l}\text { Year } \\
\text { Hospitalization } \\
\text { expenses }\end{array}$} & \multicolumn{2}{|l|}{2013} & \multicolumn{2}{|l|}{2014} & \multicolumn{2}{|l|}{2015} & \multicolumn{2}{|l|}{2016} & \multicolumn{2}{|l|}{2017} & \multicolumn{2}{|l|}{ Total } \\
\hline & $\begin{array}{l}\text { Median } \\
\text { (CNY) }\end{array}$ & $\begin{array}{l}\text { Mean } \\
\text { (CNY) }\end{array}$ & $\begin{array}{l}\text { Median } \\
\text { (CNY) }\end{array}$ & $\begin{array}{l}\text { Mean } \\
\text { (CNY) }\end{array}$ & $\begin{array}{l}\text { Median } \\
\text { (CNY) }\end{array}$ & $\begin{array}{l}\text { Mean } \\
\text { (CNY) }\end{array}$ & $\begin{array}{l}\text { Median } \\
\text { (CNY) }\end{array}$ & $\begin{array}{l}\text { Mean } \\
\text { (CNY) }\end{array}$ & $\begin{array}{l}\text { Median } \\
\text { (CNY) }\end{array}$ & $\begin{array}{l}\text { Mean } \\
\text { (CNY) }\end{array}$ & $\begin{array}{l}\text { Median } \\
\text { (CNY) }\end{array}$ & $\begin{array}{l}\text { Mean } \\
\text { (CNY) }\end{array}$ \\
\hline Medications & 10,246 & 14,204 & 19,973 & 21,044 & 16,071 & 19,234 & 9740 & 12,762 & 3995 & 7265 & 12,688 & 15,391 \\
\hline Laboratory tests & 2414 & 2768 & 2769 & 2872 & 2788 & 3020 & 2894 & 3180 & 2704 & 2844 & 2826 & 3015 \\
\hline Examinations & 3589 & 3373 & 4340 & 4271 & 4293 & 4644 & 3917 & 4140 & 2932 & 3656 & 4041 & 4186 \\
\hline $\begin{array}{l}\text { Medical service } \\
\text { charges }\end{array}$ & 398 & 789 & 618 & 844 & 700 & 967 & 804 & 1104 & 517 & 797 & 654 & 963 \\
\hline Total & 17,465 & 21,134 & 27,289 & 29,031 & 24,573 & 27,865 & 17,315 & 21,186 & 9780 & 14,562 & 20,268 & 23,555 \\
\hline
\end{tabular}

AIDS acquired immune deficiency syndrome, CNY Chinese Yuan 
Table 5 Uni-variate analysis of hospitalization expenses for HIV and AIDS inpatients

\begin{tabular}{|c|c|c|c|c|c|c|}
\hline \multirow[t]{2}{*}{ Factors } & \multicolumn{3}{|l|}{ HIV patients } & \multicolumn{3}{|l|}{ AIDS patients } \\
\hline & $\begin{array}{l}\text { Median (IQR) } \\
\text { (CNY) }\end{array}$ & $\mathrm{H}$ & $P$-Value & $\begin{array}{l}\text { Median (IQR) } \\
\text { (CNY) }\end{array}$ & $\mathrm{H}$ & $P$-Value \\
\hline \multicolumn{2}{|l|}{ Gender } & -2.288 & 0.022 & & 1.251 & 0.211 \\
\hline Male & $3372(3025-4123)$ & & & $20,914(9155-33,332)$ & & \\
\hline Female & $4133(3238-8044)$ & & & $17,616(9837-27,135)$ & & \\
\hline \multicolumn{2}{|l|}{ Age groups (years) } & 5.683 & 0.128 & & 0.607 & 0.895 \\
\hline$<30$ & $3437(3095-6365)$ & & & $19,751(8602-32,644)$ & & \\
\hline $30-44$ & $3328(2942-4346)$ & & & $21,426(8903-35,004)$ & & \\
\hline $45-59$ & $3561(3113-5060)$ & & & $19,856(10,366-32,935)$ & & \\
\hline $60-73$ & $5041(3391-12,078)$ & & & $19,269(12,538-31,723)$ & & \\
\hline \multicolumn{2}{|l|}{ Transmission route } & 4.815 & 0.090 & & 5.167 & 0.076 \\
\hline MSM & $3272(3113-3516)$ & & & $14,409(3569-31,872)$ & & \\
\hline Heterosexual & $3561(3025-6365)$ & & & $20,329(9708-33,558)$ & & \\
\hline Other/unknown & $3406(2690-5842)$ & & & $21,477(12,049-31,715)$ & & \\
\hline \multicolumn{2}{|c|}{ Length of hospital stay (days) } & 32.467 & $<0.001$ & & 253.559 & $<0.001$ \\
\hline$<10$ & $3265(2916-3765)$ & & & $5053(3145-8875)$ & & \\
\hline $10-19$ & 3874 (3489-7203) & & & $14,324(8791-18,890)$ & & \\
\hline $20+$ & $10,858(10,446-26,053)$ & & & $30,578(22,942-39,682)$ & & \\
\hline \multicolumn{2}{|c|}{ 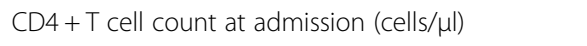 } & -0.929 & 0.353 & & -4.155 & $<0.001$ \\
\hline$<200$ & $3820(3384-8052)$ & & & 23,097 $(9879-35,104)$ & & \\
\hline $200+$ & $3489(3029-5060)$ & & & $14,691(8947-21,013)$ & & \\
\hline \multicolumn{2}{|l|}{ Complications } & - & - & & 99.487 & $<0.001$ \\
\hline 0 & $3489(3072-5060)$ & & & $7668(3944-16,911)$ & & \\
\hline 1 & - & & & $17,982(10,295-29,991)$ & & \\
\hline 2 & - & & & $25,932(17,265-36,988)$ & & \\
\hline $3+$ & - & & & $31,105(20,336-37,533)$ & & \\
\hline
\end{tabular}

HIV human immunodeficiency virus, AIDS acquired immune deficiency syndrome, MSM men who have sex with men, IQR interquartile range

more difficult to treat, leading to rising costs. In September 2015, the World Health Organization released updated treatment guidelines which recommended that ART be provided to all patients diagnosed with HIV, regardless of CD4+ T cell count [19]. Early detection and treatment to control viral load levels and improve $\mathrm{CD} 4+\mathrm{T}$ cell counts are integral steps to reducing the risk of AIDS complications, and are thus, an ideal way to reduce the economic burden on patients and their families.

According to the findings from this study, the strongest predictor of higher hospital expenses was length of

Table 6 Effect decomposition of factors on hospitalization expenses for HIV/AIDS inpatients

\begin{tabular}{|c|c|c|c|c|c|c|c|c|c|c|}
\hline \multirow[t]{2}{*}{ Factors } & \multicolumn{5}{|c|}{ HIV patient } & \multicolumn{5}{|c|}{ AIDS patient } \\
\hline & $\begin{array}{l}\text { Direct } \\
\text { effect }\end{array}$ & $\begin{array}{l}\text { Indirect } \\
\text { effect }\end{array}$ & $\begin{array}{l}\text { Total } \\
\text { effect }\end{array}$ & $\begin{array}{l}\text { Correlation } \\
\text { coefficient } \\
\text { with } Y_{1}\end{array}$ & $\begin{array}{l}\text { Correlation } \\
\text { coefficient } \\
\text { with } Y_{2}\end{array}$ & $\begin{array}{l}\text { Direct } \\
\text { effect }\end{array}$ & $\begin{array}{l}\text { Indirect } \\
\text { effect }\end{array}$ & $\begin{array}{l}\text { Total } \\
\text { effect }\end{array}$ & $\begin{array}{l}\text { Correlation } \\
\text { coefficient } \\
\text { with } Y_{3}\end{array}$ & $\begin{array}{l}\text { Correlation } \\
\text { coefficient } \\
\text { with } Y_{4}\end{array}$ \\
\hline $\begin{array}{l}\text { In (Length of hospital } \\
\text { stay) }\end{array}$ & 0.563 & - & 0.563 & 1.000 & $0.568^{a}$ & 0.649 & - & 0.649 & 1.000 & $0.727^{\mathrm{a}}$ \\
\hline Female & 0.217 & - & 0.217 & 0.020 & $0.228^{a}$ & - & - & - & - & - \\
\hline Complication = 1 & & - & - & - & - & 0.241 & -0.009 & 0.232 & -0.076 & -0.035 \\
\hline Complications $=2$ & - & - & - & - & - & 0.359 & 0.062 & 0.421 & $0.195^{a}$ & $0.291^{\mathrm{a}}$ \\
\hline Complications $\geq 3$ & - & - & - & - & - & 0.263 & 0.023 & 0.286 & $0.102^{a}$ & $0.172^{\mathrm{a}}$ \\
\hline
\end{tabular}

a there is a correlation, the hypothesis test of the correlation coefficient $(P<0.05)$. HIV human immune deficiency virus, AIDS acquired immune deficiency syndrome 


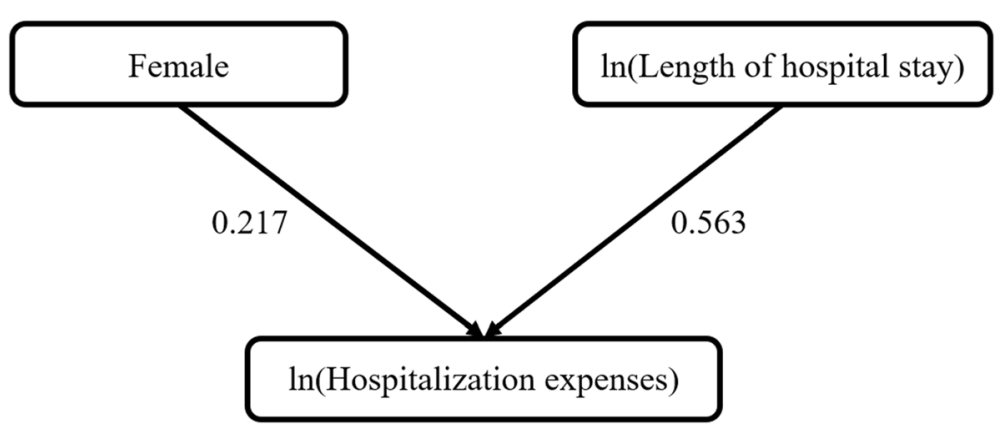

Fig. 1 Path chart of hospitalization expenses for HIV patients

hospital stay (total path coefficient $=0.563$ and 0.649 , respectively for people living with HIV and AIDS patients). In our study the average length of hospital stay was 19.0 days, much higher than a study in South Africa, which reported an average length of stay of 9.3 days for HIVpositive admissions [7]. The average length of hospital stay is an important indicator, which can reflect the efficiency of hospitals in China. Without affecting the patient's treatment, the hospital should take certain measures to reduce the length of hospital stay, which not only reduces the patient's hospitalization expenses, but also improves the utilization rate of hospital medical resources. Expanded medical training of staff, as well as efforts to promote ART adherence may be preventive factors, which could help reduce medical expenditure in the long-term.

These findings should be considered in light of the study limitations. The cost in our study was lack of the fee of ART for its paid by the government. Participants in this study were limited to one infectious disease hospital in a low prevalence area in eastern China and as such, findings may not be generalizable to the other patients across the country. Additionally, in this study, we did not distinguish between the amounts paid by the patient and the amounts paid by their insurance companies. As such, further analysis addressing the true direct costs, supplemented with the potential impact on indirect costs, is needed. Further follow-up, which captures total hospitalizations costs of the patient, particularly out-of-pocket expenses and other associated costs of care not captured in this initial assessment, would help inform the true cost of HIV/AIDS care in Nantong City.

\section{Conclusions}

Our study found that for HIV patients, laboratory fees was the largest contributor to expenses, while gender and length of hospital stay were the factors related to higher hospitalization expenses. For AIDS patients, associated drug fees was the most expensive part of care, and the number of complications and length of hospital stay had a significant impact on hospitalization expenses. Therefore, comprehensive measures such as early detection and treatment, promotion of ART adherence, efforts to shorten length of hospital stay, as well as reduce the associated laboratory and drug fees, are critical ways to reduce these costs and reduce the economic burden of the disease.

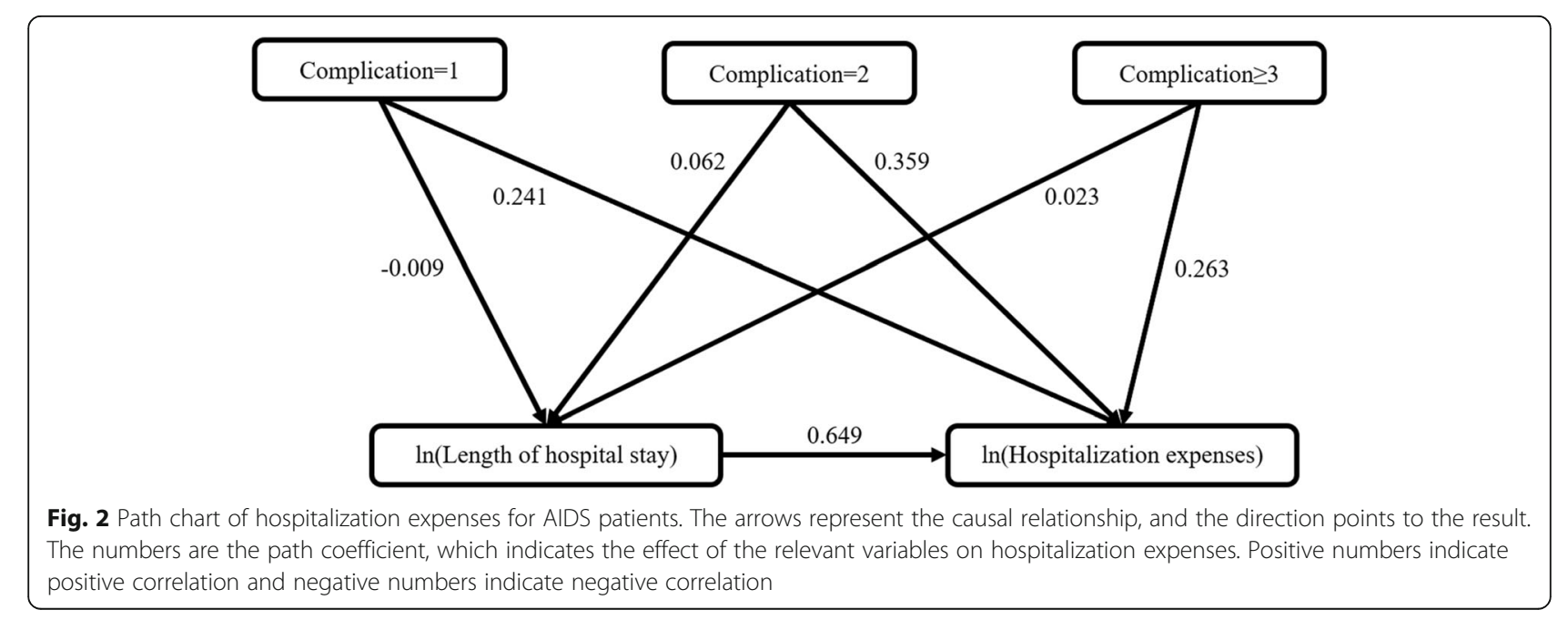




\section{Abbreviations}

ADEs: Adverse events; AIDS: Acquired immunodeficiency syndrome; ART: Antiretroviral therapy; ARV: Antiretroviral; CPI: Consumer price index; CMV: Cytomegalovirus; CNY: Chinese Yuan; CRP: C-reactive protein; $C T$ : Computed tomography; EBV: Epstein-Barr virus; ECG: Electrocardiogram; HAART: Highly active antiretroviral therapy; HIV: Human immunodeficiency virus; IQR: Inter-quartile range; MRI: Magnetic resonance imaging; MSM: Men who have sex with men; Ols: Opportunistic infections; RMB: Renminbi; SDs: Standard deviations

\section{Acknowledgements}

Not applicable.

\section{Authors' contributions}

XZ and YJC participated in collecting data, analyzing data, and drafting the article. ZYW, SRS, RFL, ZCX, YHY, WW, LYC and YYL participated in data analyses and revised the article. GQ and MYZ contributed to the design and coordination of the study. All authors read and approved the final manuscript.

\section{Funding}

This work was funded by Precision Targeted Intervention Studies among High Risk Groups for HIV Prevention in China, National Science and Technology Major Project (2018ZX10721102), the key Project of Philosophy and Social Sciences Research in Jiangsu Education Department (2018SJZDI123), the Nantong Municipal Bureau of Science and Technology (MS12018001), Postgraduate Research \& Practice Innovation Program of Jiangsu Province (KYCX18_2432). The funders had no roles in the study design, collecting data, the analysis and interpretation of data, or writing the manuscript.

\section{Availability of data and materials}

The datasets used and/or analyzed during the current study are available from the corresponding author on reasonable request.

\section{Ethics approval and consent to participate}

This study was approved by the Ethics Committee of Affiliated Infectious Disease Hospital of Nantong University. As this was a retrospective analysis of de-identified records data (i.e., no personally identifying information was collected), informed consent was not required.

\section{Consent for publication}

Not applicable.

\section{Competing interests}

The authors declare that they have no competing interests.

\section{Author details}

'Department of Epidemiology and Biostatistics, School of Public Health, Nantong University, Nantong, Jiangsu 226019, People's Republic of China. ${ }^{2}$ Nantong Center for Disease Control and Prevention, Nantong, Jiangsu 226007, People's Republic of China. ${ }^{3}$ National Center for AIDS/STD Control and Prevention, Chinese Center for Disease Control and Prevention, Beijing 100872, People's Republic of China. ${ }^{4}$ Affiliated Infectious Disease Hospital of Nantong University, Nantong, Jiangsu 226000, People's Republic of China.

Received: 12 August 2019 Accepted: 24 August 2020

Published online: 31 August 2020

\section{References}

1. UNAIDS. Global HIV \& AIDS statistics - 2018 fact sheet. 2018. http://www unaids.org/en/resources/fact-sheet. Accessed 26 July 2019.

2. NCAIDS, NCSTD, CDC China. Update on the AIDS/STD epidemic in China in December, 2017. Chin J AIDS STD. 2018;3:111.

3. Wang L, Qin QQ, Ding ZW, Li PL, Hei FX, Wang LY, et al. Current case reporting of HIV/AIDS epidemic in China. Chin J AIDS STD. 2011;3:275-8.

4. Li DS, Liu J, Wang Z. Advance of antiretroviral treatment as effective measures to prevent transmission HIV. Chin J AIDS STD. 2016;022(002): 133-7.

5. WHO. Burden of disease: what is it and why is it important for safer food? https://www.who.int/foodsafety/foodborne_disease/Q\&A.pdf. Accessed 26 July 2019.
6. Léotoing LD, Yazdanpanah Y, Finkielsztejn L, Chaize G, Vainchtock A, Nachbaur G, et al. Costs associated with hospitalisation in Hiv-positive patients in France. Aids. 2018;32:1.

7. Long LC, Fox MP, Sauls C, Evans D, Sanne I, Rosen SB. The high cost of HIVpositive inpatient Care at an Urban Hospital in Johannesburg. South Africa PLoS One. 2016;11(2):e0148546.

8. State Council. Notice on effectively strengthening AIDS prevention and control of state council. 2004. http://www.gov.cn/zhengce/content/200803/28/content_6318.htm. Accessed 26 July 2019

9. Li YM, Wu JX, Zhang HD. Analysis of hospitalization expenses of opportunity infection treatment in AIDS patients. Chin Med Rec. 2017:18(12):91-3.

10. Wan J, Yang G, Huang LH, Xu YJ, Wang Y, Chen C, et al. Health expenses and medical insurance among people living with HIV / AIDS based on retrospective survey in the high HIV epidemic area. Med Soc. 2015;3:19-22.

11. Wang Y, Xu P, Zhou Y, Ge LR. Hospitalization expenses of opportunity infection treatment among female patients with AIDS. Pract Prev Med. 2016;23(8):897-9.

12. Yang $X B$, Zhu MR, Chen DD, Zhu YC, Wang DJ. Antiretroviral therapy related direct economic burden and its impact factors in patients living with HIV/ AIDS in Liangshan Yi autonomous region. Chin J Public Health. 2019; 035(002):197-201.

13. National Health Commission of the People's Republic of China. Diagnosis for HIV/AIDS. 2019. http://www.nhc.gov.cn/fzs/s7852d/201901/9493bdd154 9b4908be18beb6007b009d/files/26c00442e5484b2ba98a8d31c2a4f453.pdf. Accessed 26 July 2019

14. Godin G, Côté J, Naccache H, Lambert LD. S T. prediction of adherence to antiretroviral therapy: a one-year longitudinal study. AIDS Care. 2005;17(4): 493-504.

15. Zhou F, Kominski GF, Qian HZ, Wang J, Duan S, Guo Z, et al. Expenditures for the care of HIV-infected patients in rural areas in China's antiretroviral therapy programs. BMC Med. 2011;9(1):6.

16. Yang $C M$, Yu AL, Li L, Zhou YQ, Bai L. Multiple regression analysis of factors influencing the costs of treatment for AIDS. Chin J Viral Dis. 2014;2:118-21.

17. Carpenter CC, Fischl MA, Hammer SM, Hirsch MS, Jacobsen DM, Katzenstein DA, et al. Antiretroviral therapy for HIV infection in 1997. Updated recommendations of the international AIDS society-USA panel. JAMA. 1998; 277(24):1962-9.

18. Xie BS, Zhou B, Qin XZ. Analysis of hospitalization expenses for AIDS patients in a hospital in Guangxi. Chin J AIDS STD. 2014;20(04):278-9+82.

19. WHO. Guideline on when to start antiretroviral therapy and on preexposure prophylaxis for HIV. 2015. https://apps.who.int/iris/bitstream/ handle/10665/186275/9789241509565_eng.pdf;jsessionid=9AA9519F24 9DA028FD298D80966580A5? sequence=1. Accessed 26 July 2019 .

\section{Publisher's Note}

Springer Nature remains neutral with regard to jurisdictional claims in published maps and institutional affiliations.

Ready to submit your research? Choose BMC and benefit from:

- fast, convenient online submission

- thorough peer review by experienced researchers in your field

- rapid publication on acceptance

- support for research data, including large and complex data types

- gold Open Access which fosters wider collaboration and increased citations

- maximum visibility for your research: over $100 \mathrm{M}$ website views per year

At $\mathrm{BMC}$, research is always in progress.

Learn more biomedcentral.com/submission 